\title{
Sedimentary petrological characteristics of lateral and frontal moraine and proglacial glaciofluvial sediments of Bertilbreen, Central Svalbard
}

\author{
Martin Hanáček ${ }^{1 *}$, Jan Flašar ${ }^{2}$, Daniel Nývlt ${ }^{3}$ \\ ${ }^{1}$ Department of Geological Sciences, Masaryk University, Kotlářská 2, 61137 Brno, \\ Czech Republic \\ ${ }^{2}$ Department of Geology and Palaeontology, Faculty of Science, Charles University in \\ Prague, Albertov 6, 12843 Praha 2, Czech Republic \\ ${ }^{3}$ Czech Geological Survey - Brno Branch, Leitnerova 22, 65869 Brno, Czech Republic
}

\begin{abstract}
Bertilbreen is a valley glacier located in the central part of the Spitsbergen Island, Svalbard. Glacier bedrock is composed of Devonian Old Red facies sedimentary rocks, Carboniferous clastic sedimentary rocks and Carboniferous to Permian limestones. Cobble clasts from the right-hand lateral moraine, frontal moraine and proglacial glaciofluvial sediments were studied. The upper part of the lateral moraine is composed mostly of passively transported supraglacial debris (originally unmodified scree, snow and scree/rock avalanche deposits) with a small proportion of actively transported clasts or reworked glaciofluvial sediments. Clasts in the middle part of the lateral moraine originate predominantly from the frontal moraine of a small glacier in the lateral valley. The lower part of the lateral moraine and frontal moraine of Bertilbreen are rich in subglacially transported material, which is supported by isometric clast shapes, roundness degree and common clast surface striations. Coarse gravel forms longitudinal bars in the glaciofluvial stream flowing from the glacier front. In the southern mouth of the valley, the proglacial stream grades into a braided outwash fan. Clast nature is affected by the source from the surrounding glacial deposits and bedrock outcrops, the impact of glaciofluvial transport on the clast nature increases in the braided outwash fan. Clast shapes are primarily influenced by bedding and fractures of source rocks, but are also significantly influenced by the type and proximity of material sources. Striation is cleared away the clast surface during the glaciofluvial transport. A morphostratigraphically older glaciofluvial terrace formed by glaciofluvial sediments deposited during the glacier advance culminating during the Little Ice Age (LIA) is located at the southern end of the valley. The comparison of active proglacial stream sediments and those from older glaciofluvial terrace was done using the coarse pebble fraction.
\end{abstract}

Key words: Petrology, clast shape, clast roundness, clast striation, lateral and frontal moraine, proglacial glaciofluvial stream, Bertilbreen, Svalbard

\footnotetext{
Received November 5, 2011, accepted December 5, 2011.

*Corresponding author: HanacekM@seznam.cz

Acknowledgement: This research was undertaken in July 2011 during the Course of the Polar Ecology organized by the Faculty of Science, University of South Bohemia in České Budějovice (project nr. MSMT-CzechPolar-LM2010009). The authors would like to thank to Vojtěch Jirásek for the help in the field and Josef Elster for organizing this course.
} 


\section{Introduction}

Sediments of recent glaciers have widely been studied during last decades, focusing mainly on the description of individual sediment types using clast shape and roundness and the reconstruction of debris transport history in the glacial system (e.g. Boulton 1978, Benn et Ballantyne 1994, Bennett et al. 1997, Evans 1999, Adam et Knight 2003,

\section{Study area}

Betrilbreen is located in the central part of Spitsbergen Island (Dickson Land), 2.5 $\mathrm{km}$ NNW of the Russian mining town Pyramiden (Fig. 1). It is a valley type of glacier with two accumulation areas. The first one is made of the cirque below the Reuterskiöld Hill (Reuterskiöldfjellet, $1027 \mathrm{~m}$ ) and an un-named peak (835 m) located towards the South (Fig. 2). The second accumulation area is composed by cirques SE of Reuterskiöldfjellet, where ice-divide with Ferdinandbreen is located. The Bertilbreen is flowing towards the South and has a $\sim 3 \mathrm{~km}$ long tongue.

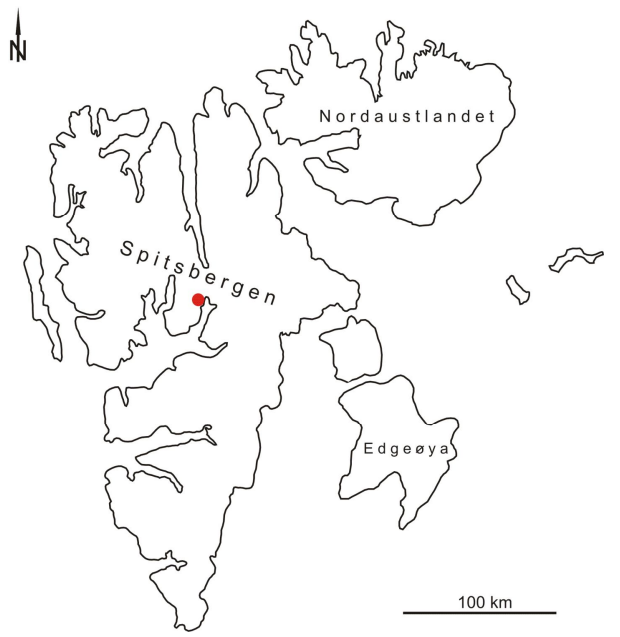

Fig. 1. Svalbard archipelago with red point indicating the studied area of Bertilbreen.
Hambrey et Ehrmann 2004). This study provides further contribution to this research focusing on the glacier tongue of Betrilbreen on Svalbard. Sedimentary petrological results are combined with lithofacial description and morphology of sedimentary bodies to bring a more complex insight into the young deposition history of this glacier system.

Bertilbreen is receding for at least the last century similarly to other glacier in the area (Rachlewicz et al. 2007). Present glacier front of Bertilbreen is located in the distance of the right-hand hanging valley, where an unnamed glacier tongue advanced formerly (Fig. 3). The maximum historical advance of Bertilbreen from the Little Ice Age (LIA; Rachlewicz et al. 2007) is marked by frontal moraine located $\sim 2 \mathrm{~km}$ south of the present glacier front (Fig. 2).

The basement of the Bertilbreen is made of sedimentary rocks (see Fig. 4; Dallmann et al. 2004). The base and lower sidewall parts are built of reddish and greenish sedimentary rocks of Devonian Old Red facies. They compose thick formation of fine- to medium-grained sandstones and siltstones, which is steeply inclined tectonically. Lower Carboniferous clastic formation overlies Old Red facies in the eastern side of the valley. It consists of alternating layers of light-coloured sandstone, grey to black siltstone and coal seams. Stigmaria and other plant remains are common in these sediments. They lie below the glacier in the area NW of the Mumien Peak $(770 \mathrm{~m})$. Upper Carboniferous and Permian limestones crop out in the middle and northern part of the western sidewall of the glacier. They build up the upper valley sides and the summit of the range, where cirques feeding the 
Bertilbreen are located. Limestone has also small outcrops on the western slope of Mumien Peak. Sedimentary rocks of Old Red facies crop out predominantly in the southern part of the valley. They are exposed in a small canyon, which was eroded by proglacial stream. The canyon begun to evolve in a place, where the stream eroded the frontal moraine. Therefore, it can be found mostly in its forefield (Fig. 5G, 7B and 8A).

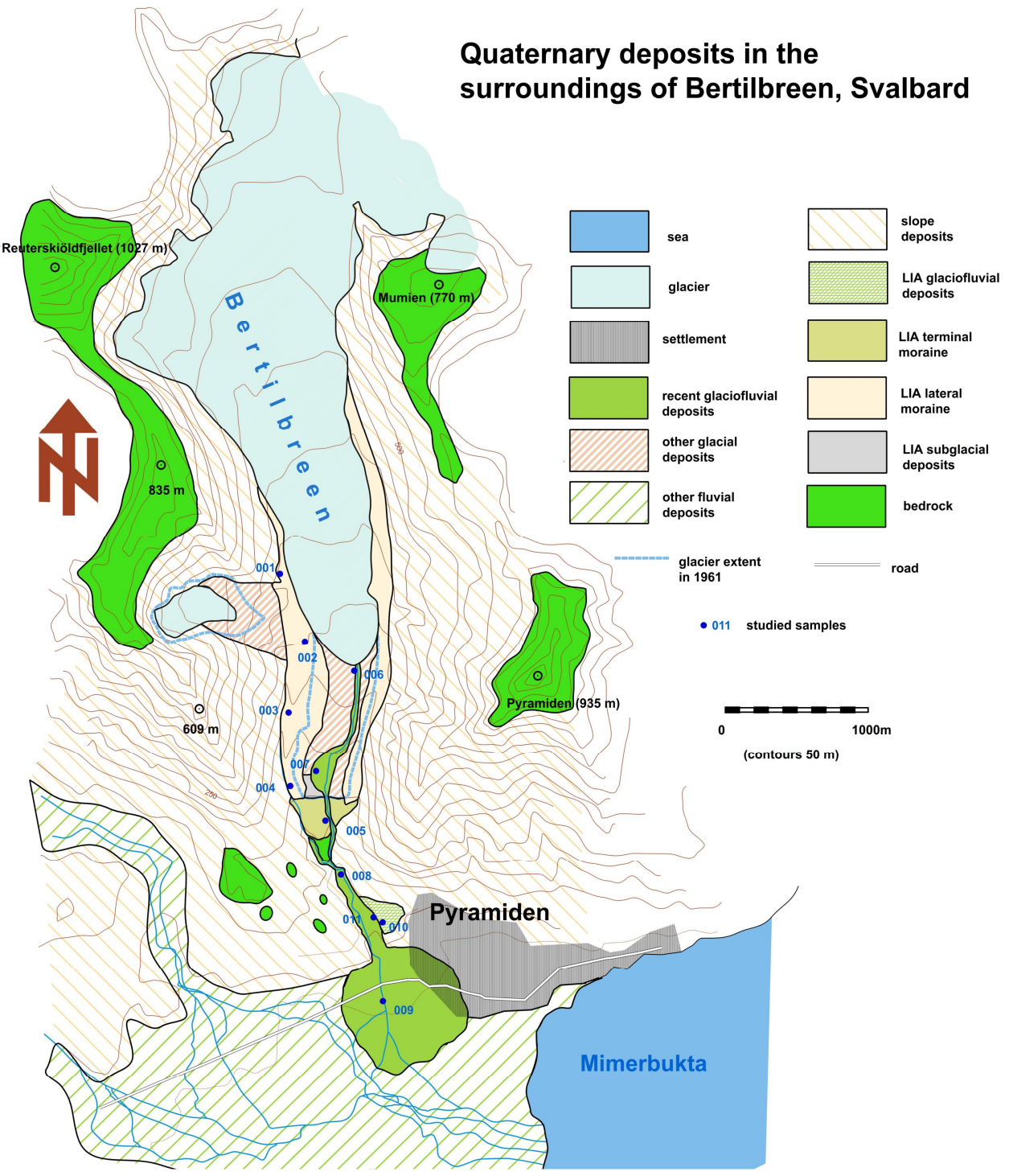

Fig. 2. Quaternary map of the Bertilbreen valley, modified from Dallmann et al. (2004). 


\section{Material and Methods}

The morainic sediments were classified using the Moncrieff (1989) classification of unsorted deposits. We focused especially on the petrological composition, shape, roundness and striation of glacial sediments in this study. Clast petrological analyses of samples 001-009 were studied in the 64-256 $\mathrm{mm}$ b-axis fraction, which is best for comparison of these sediments. Samples 001-004 originates from righthand lateral moraine, sample 005 from frontal moraine, samples 006-009 from longitudinal bars of the active glaciofluvial stream. Samples 010 and 011 compared active glaciofluvial stream and older glaciofluvial terrace sediments using the 32-64 $\mathrm{mm}$ b-axis fraction. Sampling was carried out using standardized sieves directly from the outcrop in the cut-bank of the older glaciofluvial terrace and from the surface of an active proglacial stream. The 32-64 $\mathrm{mm}$ b-axis fraction was chosen, as it is representative for both these sedimentary bodies. Each analysis includes 100 counted clasts. Ternary diagrams of Sneed et Folk (1958) were employed to present clast shapes. Roundness was evaluated using the method described by Powers (1953). Covariant plot of $\mathrm{C}_{40}$ and $\mathrm{RA}$ indices introduced by Benn et Ballantyne (1994) was used for a mutual comparison of all types of studied sediments. The $\mathrm{C}_{40}$ index gives the percentage of clasts with a proportion of the short to long axes (c/a) $<0.4$. The RA index is defined as the percentage of very angular and angular clasts in the sample.

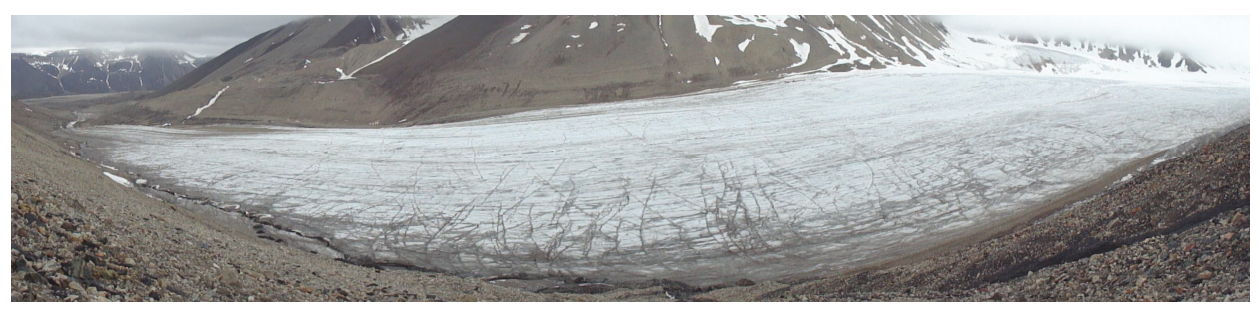

Fig. 3. Bertilbreen, view from the East, from the ridge between the Pyramiden (935 $\mathrm{m})$ and Mumien (770 m) Peaks.

\section{Results}

Different genetic types of glacial sediments are present in the terminoglacial and proglacial zone of Bertilbreen glacier system. They could be primarily distinguished to diamictons building moraine ridges, subglacial deposits and glaciofluvial sediments. All sediment types are generally coarse-grained; with predominance of pebbles and cobbles, however boulders are present as well. The distribution of Quaternary sediments in the Bertilbreen valley is shown in Fig. 2.

Conglomerate to clast-rich sandy diamicton forming ridge shaped ice-cored mounds with steep slopes are common at the glacier margin and in its immediate forefield (Fig. 5A, 5B). Pebbles, cobbles and boulders of different roundness are commonly striated. Parallel stripes of very angular to angular limestone clasts are present on the glacier surface in its ablation zone (Fig. 5C). Small elevations made of (subglacial and englacial) glaciofluvial sediments are also preserved in front of the glacier.

Lateral moraines are present on the valley sides, but the left-hand valley side was anthropogenetically strongly affected 
by coal mining activities. The right-hand lateral moraine is composed of coarse gravel clasts and some boulders with mostly angular to subangular clasts (Fig. $5 \mathrm{~F})$. The sediments are clast-supported with matrix being present only exceptio- nally. The clast petrology is depending on the outcrops in the western valley side. The lateral moraine sediments are nearly monomict at places as it is almost exclusively made up of limestone or Old Red sandstone facies clasts.

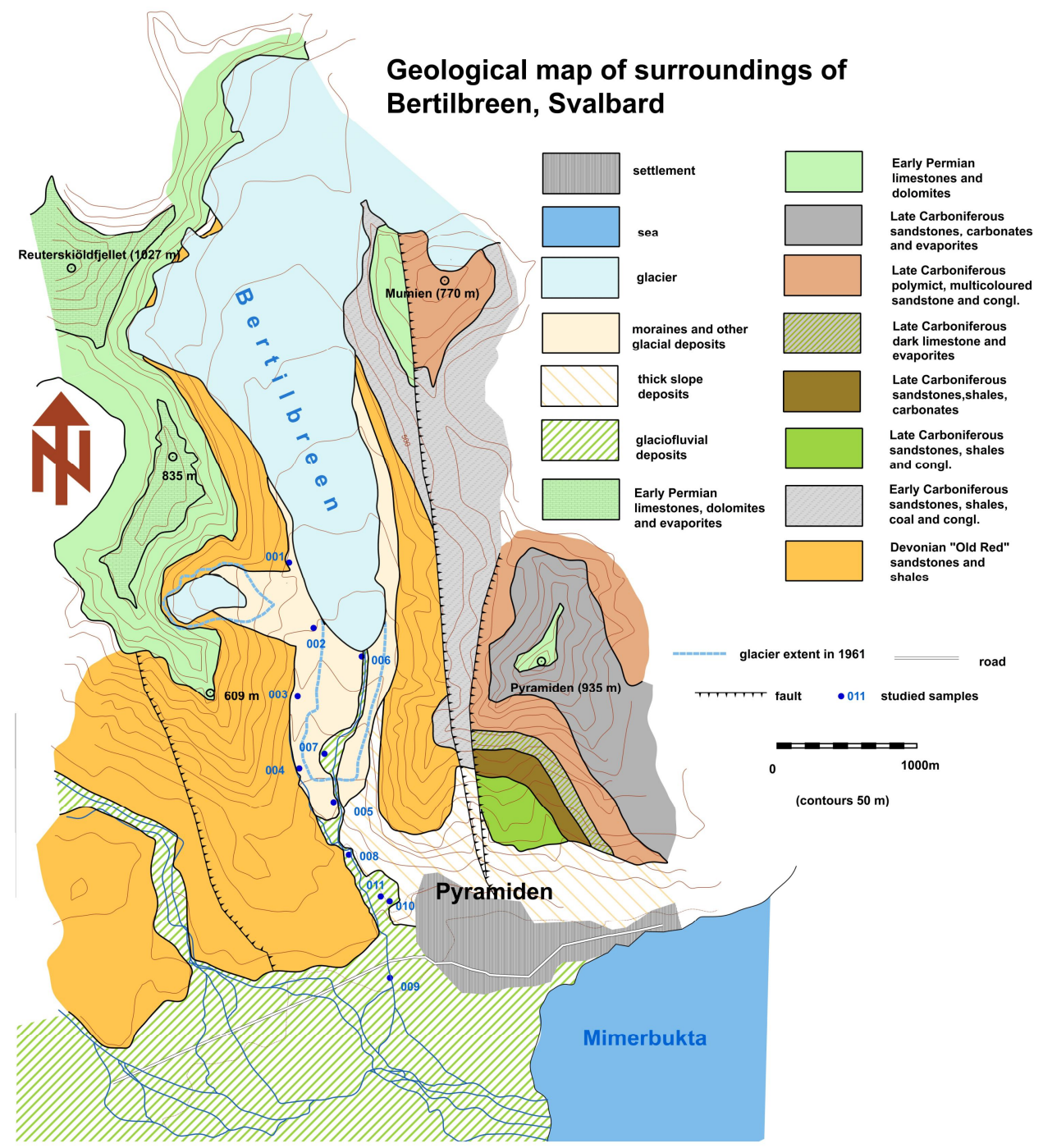

Fig. 4. Geological map of pre-Quaternary and simplified Quaternary units in the Bertilbreen valley, modified from Dallmann et al. (2004). 
The frontal moraine is composed of clasts with a wide range of size and roundness (Fig. 5H). Pebbles and cobbles with a diameter $<10 \mathrm{~cm}$ predominates, but clasts larger than $20 \mathrm{~cm}$, incl. boulders are also abundant. Gravel content is $\sim 30 \%$, the rest of the sediment consists of silty-sandy to fine-gravel matrix. The matrix shares are changeable; therefore matrix-supported sediment alternates with clast-supported ones. Gravels and boulders often bear striae on their surfaces. The frontal moraine sediment might be described as a clast-rich sandy diamicton.

The sediments covering the valley floor (except of the glaciofluvial sediments) are also diamictons (Fig. 6A). Martixsupported and clast-supported types alternates, as well as diverse roundness and size categories of the clasts. The clasts are often striated (Fig. 6B-D). The sediments have different nature at some places, where they for example consists of small patches of 5-10 cm large rounded to well rounded clasts.

Proglacial glaciofluvial stream evolves in connection with the moraine morphology and valley dip. The stream consists of one channel in the most proximal zone, while being limited by ice blocks and ice-cored debris covered elevations. Only small gravel bars occur in the channel. After a few hundreds meters from the glacier front the ice cored debris covered elevations disappear and the stream begins to braid. It changes into a wider plain with numerous braiding channels separated by rhomboidal, bladed, or ellipsoidal longitudinal bars (Fig. 7A). The bar surfaces are generally flat. The stream is constrained in the canyon, eroded in the Old Red facies rocks in front of the glacier. For this reason, the stream branches only in a few channels separated by a small number of longitudinal bars, oriented in a nearly downstream row (Fig. 7B). The stream quickly branches into a braidplain after leaving the canyon forming a broad and flat braided outwash fan (Fig. 7C) sensu (Hambrey 1994). However, only one major channel is active on the surface of the outwash fan at present, the other channels being abandoned. The flow over the bar surface during the most intense flood events erodes small channels, which are filled by finer grained gravel and sand. Three different lithofacies can be described in sections through longitudinal bars (Fig. $7 \mathrm{D}, \mathrm{E})$. The most important is the massive unsorted pebbly to cobbly gravel with sandy to fine gravely matrix-supported structure. This gravel composes flat, laterally stable sedimentary bodies. Unsorted gravel alternates with thinner and less laterally stable gravel units with pebble to cobble clast-supported structure and clear clast imbrication. The thickness of this unit corresponds to the largest clast. Thin sandy to fine gravel (up to $5 \mathrm{~cm}$ ) units appear in gravel bodies; their lateral extent reaches several meters only.

A remnant of old glaciofluvial terrace with the surface $20 \mathrm{~m}$ above the present braidplain (Fig. 8B, C) is preserved at the Bertilbreen's valley entry to the main valley near Pyramiden. The lower part of the terrace undercut is covered by scree. The middle part is made of $\sim 2.5 \mathrm{~m}$ thick set of planar (or ?trough) cross-bedded gravel. The upper part of the accumulation is formed by subhorizontal massive pebbly gravel with prevailing clast-supported structure and the admixture of $2-5 \%$ of gravel clasts reaching $10-20 \mathrm{~cm}$. Individual flat gravel bodies are sometimes covered by thin layers of laminated sand, the base of which copies the surface of large clasts (Fig. 8D). 

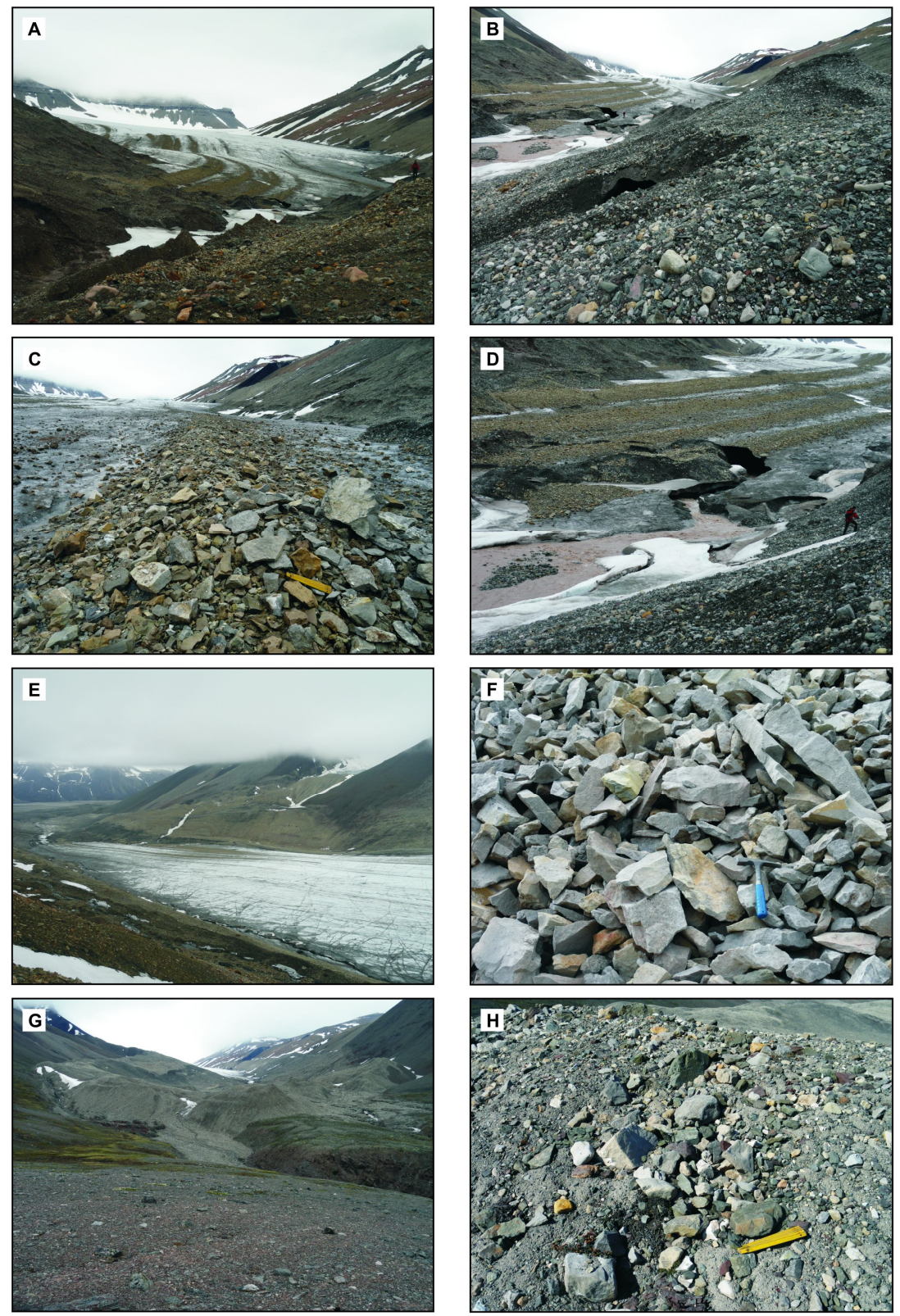

Fig. 5. A. Terminoglacial zone with stripes of ablation-dominant medial moraines and elevations of ablation moraines. B. Elevations of ablation moraine with an ice core covered by debris rich in subangular to subrounded clasts. C. Ablation-dominant medial moraine composed of angular limestone clasts. D. Glaciofluvial stream in terminoglacial zone supported by supraglacial and subglacial material. E. Right-hand lateral moraine of Bertilbreen in wider middle part. In the lateral hanging valley the glacier front and frontal moraine of an un-named glacier may be seen. F. Clast supported structure of angular limestone clasts in lateral moraine. G. Frontal moraine cutted by active glaciofluvial stream. The canyon in Old Red facies sedimentary rocks is visible in the forefield. H. Clast-rich sandy diamicton of frontal moraine. 
Gravel material originates from three primary sources, which were determined by comparing clasts with sedimentary rock units shown in the geological map of the study area (Dallmann et al. 2004). The most important sources are formations of Carboniferous and Permian limestones based on the amount of the clasts present in studied glacial sediments. Limestones forming these clasts are rather inhomogeneous, from macroscopically compact up to hornfels habit through fineto coarse organodetritic limestones up to sandy limestones. They often contain fossils of Anthozoa (Rugosa), brachiopods and bryozoans. Fusulina limestone occurs south of the entry of the hanging righthand side valley. The second source represents Old Red facies sedimentary rocks, which comprise reddish and
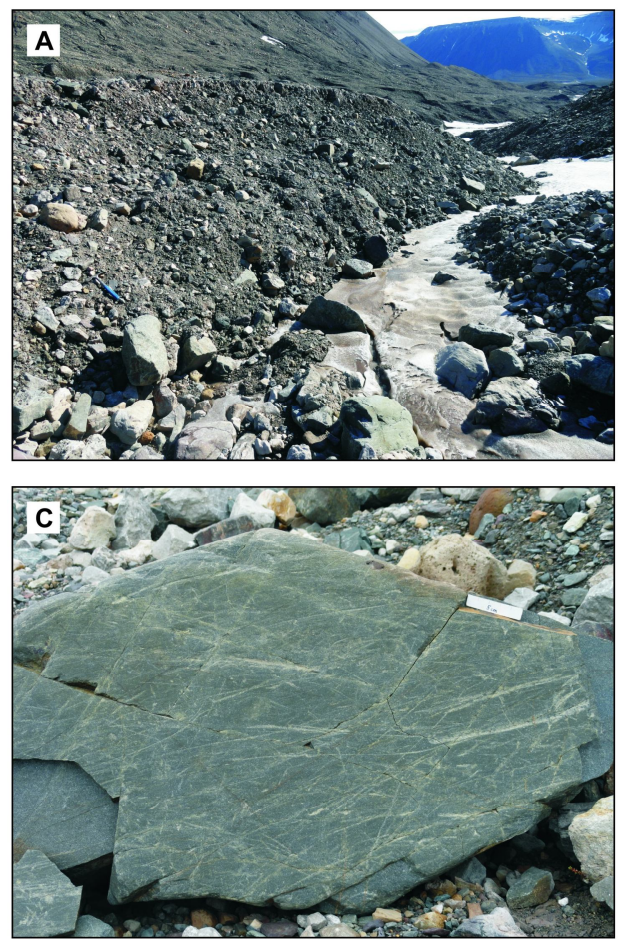

greenish mostly fine- to medium-grained sandstones, exceptionally siltstones. Third, the least important source are lower Carboniferous sedimentary rocks. These clasts consist of light sandstone (sometimes with Stigmaria), light quartz conglomerate, dark grey siltstone with Stigmaria (Stigmaria soil) and dark grey siltstone without Stigmaria. Clasts of Lower Carboniferous rocks are diverse lithologically, despite their low shares in glacial sediments. This is caused by the primary variability of Lower Carboniferous sedimentary rocks (alternating continental psammites, aleurites and coal seams with common plant fossils). The right-hand lateral moraine could be divided into three parts based on its geomorphology and sedimentary petrological results.
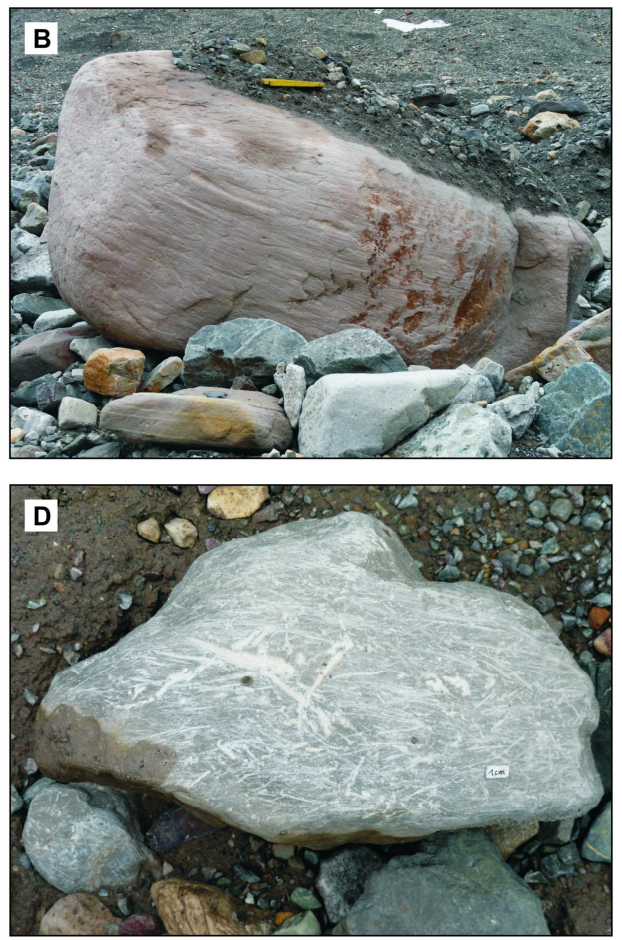

Fig. 6. A. Subglacial till at the valley floor in the proglacial zone. B. Striated boulder of Lower Carboniferous sandstone. C. Striated boulder of Old Red sandstone. D. Striated limestone boulder. 

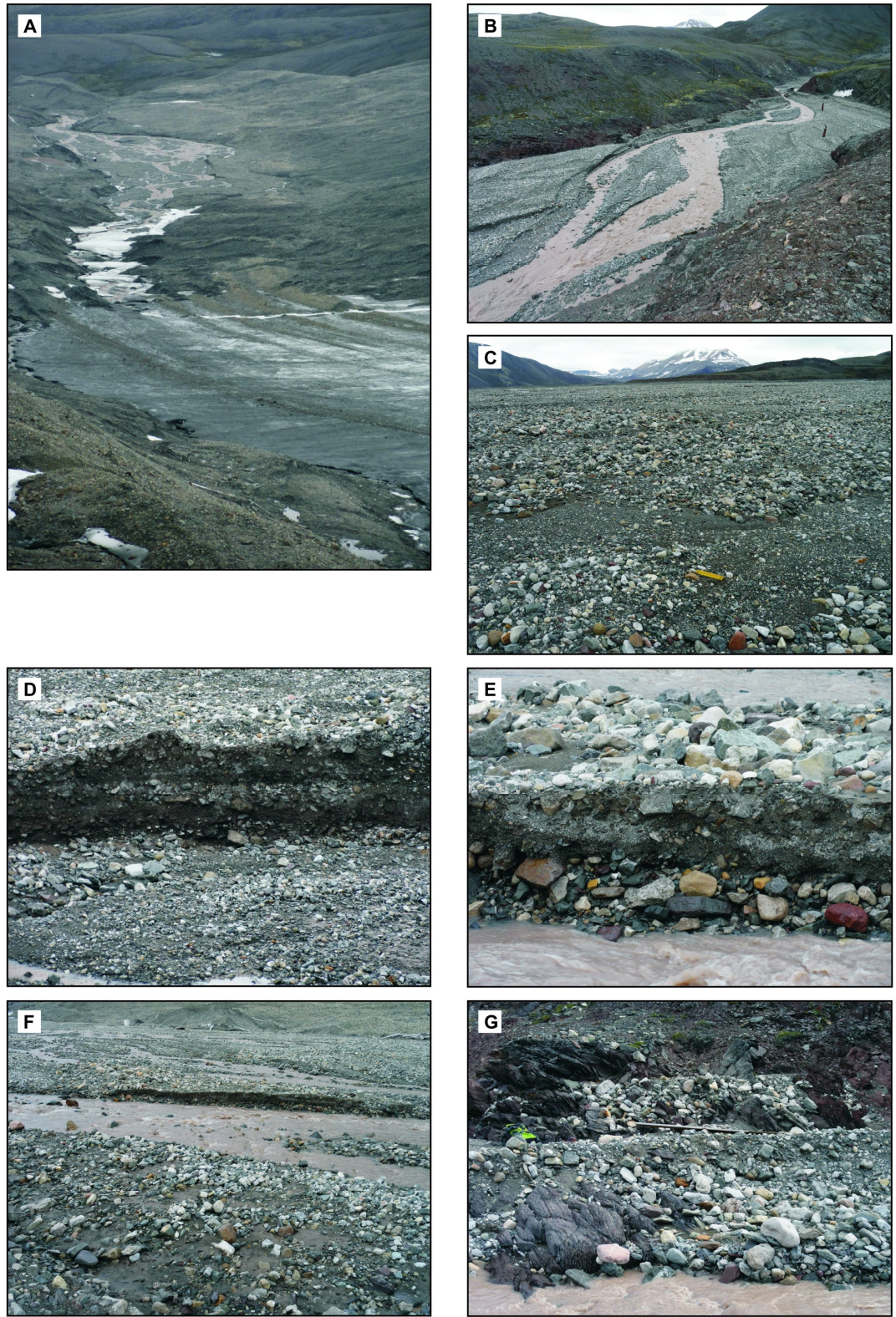

Fig. 7. A. Straight glaciofluvial stream merging to wide braidplain in proglacial zone. B. Downcutting of active glaciofluvial stream into the Old Red facies rocks. Downstream alongation of longitudinal bars is visible in the braidplain. C. Braided outwash fan surface with pebble/cobble cluster textures and fine gravel to sandy mantles. D. Section through longitudinal bar. Alternation of coarse gravel with matrix supported structure and open framework gravel facies. E. Section through longitudinal bar. Fine gravel to sandy layer between bodies of coarse cobbles. F. Stone cells textures on the bar surface. Flow direction from the left to the right. G. Imbricated coarse gravel deposited on stoss side of the Old Red facies outcrop in the canyon in front of the frontal moraine. Flow direction from the right to the left. 

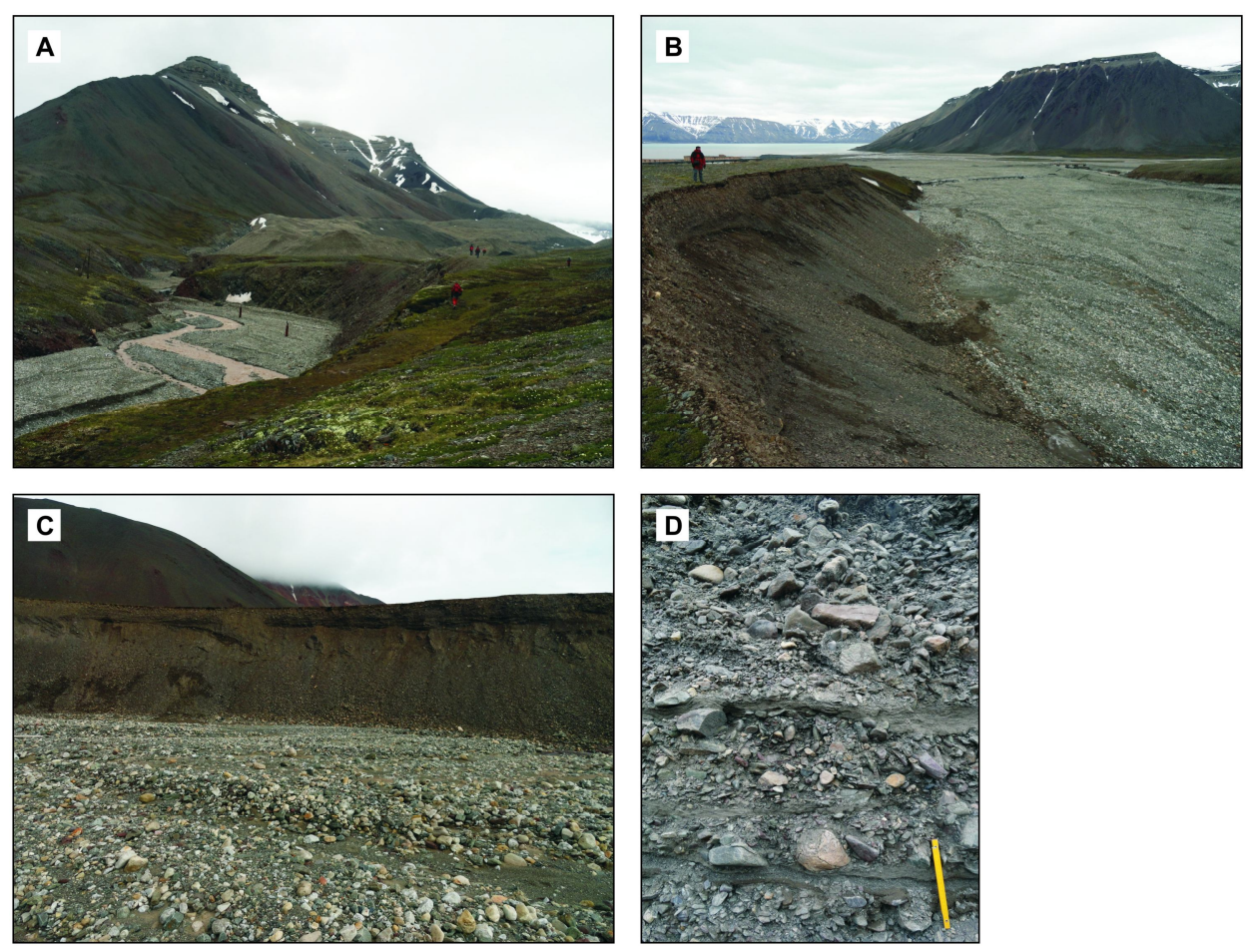

Fig. 8. A. Canyon eroded in Old Red facies rocks. The valley walls are made of Old Red facies rocks, summits are composed of subhorizontally deposited Carboniferous and Permian limestone and evaporates. Frontal and right-hand lateral moraine is visible in the middle. B. Older glaciofluvial terrace and donwcutted active glaciofluvial stream merging to braided outwash fan. C. Undercut section of older glaciofluvial terrace. Cross-bedded gravel in the middle part, subhorizontally bedded and massive gravel in the upper part of succession. D. Thin sandy layers between gravel accumulations in the upper part of the older glaciofluvial terrace succession.

The northernmost part, located north of the entry of the right-hand side valley, is composed of a narrow rim of debris with predominantly very angular to angular clasts (RA $=\sim 65 \%$ for sample 001 ). The debris rim extends to highest elevations of the right-hand lateral moraine (Fig. 5E). Talus made of Old Red facies and limestone clasts concurs with moraines along the valley sides.

The middle part of the right-hand lateral moraine is morphologically the most distinctive. This part begins at the entry of right-hand lateral valley and extends for few hundreds meters south of it. The moraine ridge widens greatly here and continues down to the proglacial zone. The lateral increase of the moraine is caused by its connection with the frontal moraine of the small un-named glacier in lateral hanging valley, which added material to the lateral moraine of Bertilbreen (Fig. 5E). A part of the moraine rim, situated closer to the entry of the lateral valley, is composed predominantly by limestone clasts; the part located further down in the proglacial zone is composed on the other hand by unmodified clasts of Old Red facies rocks. The boundary between individual petrographic components defined parts of the moraine is sharp. 
Variations in clast petrology may reflect bedrock lithology in the valley and the supply of limestone clasts by the hanging glacier. Samples from this part (samples 002 and 003) were collected from the moraine crest, in the section adjacent to the frontal moraine of the hanging glacier. The petrological composition of the middle part of the lateral moraine is compared to the upper part rather monomict, as it is composed of $\sim 90-100 \%$ of limestone clasts. Share of subangular clasts rises up to $\sim 50 \%$ here, slightly increasing is also the subrounded category.

The same clast shapes characterize the upper and middle parts of the right-hand lateral moraine. Transitional shapes between platy and compact shapes predominate (Fig. 9). Rod-like shapes are not present, which is caused by the bedrock lithology. Limestones and Old Red facies sedimentary rocks disintegrate along bedding planes and vertical fractures. They incline to thin platy shapes or on the other hand to blocky platy to compact shapes depending on the layer thickness at outcrops.

The lower part of the right-hand lateral moraine is morphologically least noticeable and extends to the lowest altitude. This part differs strongly from the middle part by an increase of Old Red facies clasts proportion $(\sim 45 \%$ in sample 004). Subangular to well rounded clasts and isometric shapes predominates. Almost a third of the clasts is striated, however striae are present only on surfaces of subangular to rounded clasts (Fig. 9).

Frontal moraine follows the lower part of right-hand lateral moraine. The share of very angular to angular clasts is even lower than at the lower part of lateral moraine (RA $=\sim 18 \%$ in sample 005). Nearly $50 \%$ of the clasts is striated.
Proglacial zone in front of Bertilbreen is $\sim 4 \mathrm{~km}$ long. Proglacial glaciofluvial sediments of the active braidplain have coarse-gravelly nature from the proximal down to the distal zone due to the high valley floor dip and primary coarsegrained nature of bedrock debris and glacigennic deposits. Equal shares of individual roundness categories and the tendency towards isometric clast shapes and thus low $\mathrm{C}_{40}$ values are observed in the terminoglacial zone (see Fig. 10). The clasts from longitudinal bars in the braidplain just behind the frontal moraine, i.e. $\sim 800 \mathrm{~m}$ from the present glacier front, are generally subrounded to subangular ( $82 \%$ in the sample 007). The shares of rounded and well rounded clasts as well as of angular and very angular ones fall comparing to terminoglacial zone. This is the only section of the glaciofluvial stream, in which clasts of the Old Red facies rocks predominates $(\sim 51 \%$ in sample 008). The increase of rounded and well rounded, but also of very angular clasts of these rocks is visible here when compared with the frontal moraine material (sample 005).

Very angular clasts are not present in the flat braided outwash fan, angular ones are represented only by $\sim 7 \%$ (sample 009 ). The roundness degree generally increases with a clear predominance of soubrounded clasts $(\sim 50 \%)$. No bedrock outcrops or other glacial deposits are present around the flat braided outwash fan to contribute to clast roundness changes.

Sediments of an older glaciofluvial terrace differ from the sediments of the active glaciofluvial stream mainly by the predominance of Old Red facies clasts $(\sim 80 \%)$, grain-size (pebbles predominates) a by though cross-bedded gravel facies creating much deeper channels. 


\section{Interpretation and discussion}

\section{Morainic sediments}

The current glacier front is covered by sediments, similarly to other glacier fronts in this area (Rachlewicz et al. 2007). Morphologically pronounced diamicton elevations in the terminoglacial zone could be interpreted as ablation moraine based on the classification of Bennett et Glasser (2010). The origin of these elevations is connected with thrusting of subglacial and englacial clastic material within the ablation zone of alpine glaciers (Boulton 1978, Bennett et al. 1997, Hambrey et al. 1997, Bennett et Glasser 2010). The fact that the terminoglacial zone has a complicated nature suggests debris covered dark ice floes in the forefield of a continuous glacier. Roundness and striation of many clasts shows on a subglacial origin (Boulton 1978) of an substantial proportion of the material. Parallel stripes of angular limestone clasts on the glacier surface represents ablationdominant medial moraines based on the classification of Bennett et Glasser (2010). The absence of rounded clasts shows that the clasts were transported passively, frozen in the glacier body. Their sources may be found in elevations completely covered by the glacier, located in its accumulation zone, where the bedrock is made of limestone.

The difference between frontal and lateral moraines is in the higher matrix proportion, variable clast roundness and an abundance of striated clasts in the frontal moraine. The material is, therefore, predominantly of subglacial origin and it was incorporated into the frontal moraine by the transport from the subglacial zone to the glacier surface along the glacier fractures or by thrusting of the material in the glacier. These processes were described from similar glaciers by Boulton (1978), Bennett et al. (1997), Hambrey et al. (1997) or Bennett et Glasser (2010). This interpretation is also supported by clast petrological analyses results, which will be discussed below.

Diamictons at the valley floor are originally subglacial, englacial and supraglacial tills. Accumulations of rounded and well rounded clasts are most likely originating from subglacial or englacial streams that could have been redeposited along the thrusting planes in the glacier. Very similar sediments are described by Bennett et al. (1997) and Bennett et Glasser (2010).

\section{Glaciofluvial sediments of an active braidstream}

Important lithofacies changes (e.g. transition from massive gravel facies to alternating gravel and sand cross-bedded facies) occur in steeply inclined proglacial valleys in the distance of $\sim 6-10 \mathrm{~km}$ from the glacier front (Boothroyd et Ashley 1975). The missing proximal-distal trend in clast's fining in proglacial glaciofluvial streams was described by Hambrey et Ehrmann (2004) due to high valley floor dip and proximity of available source of coarse-grained material. These sediments correspond to the architectural element GB (gravely bars and bedforms) of Miall (1985) based on the grain-size and lithofacies associations. Unsorted matrixsupported pebbly to cobble-gravel forming flat sedimentary bodies represents a typical facies of longitudinal bars in a proximal braidstream zone (Eynon et Walker 1974, Gustavson 1974, Boothroyd et Ashley 1975). 

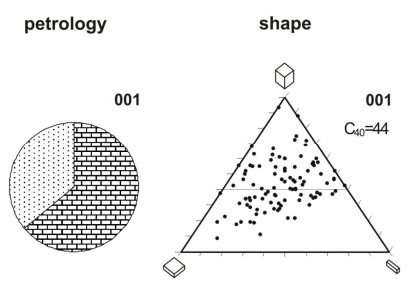

roundness

striation

legend
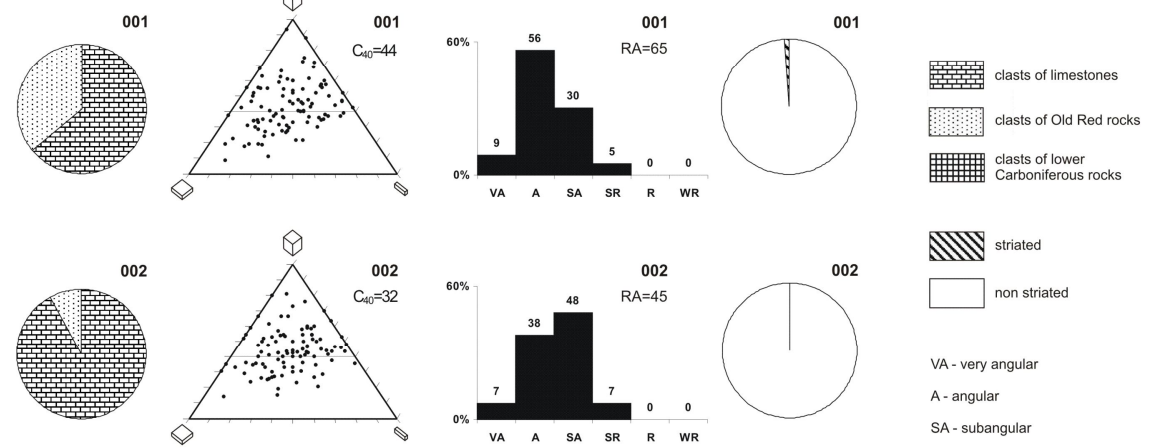

巴冊册 clasts of lower

IIIN striated
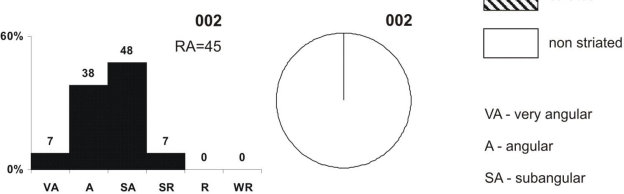

VA - very angular

A - angular

SA - subangular

SR - subrounded

$R$ - rounded
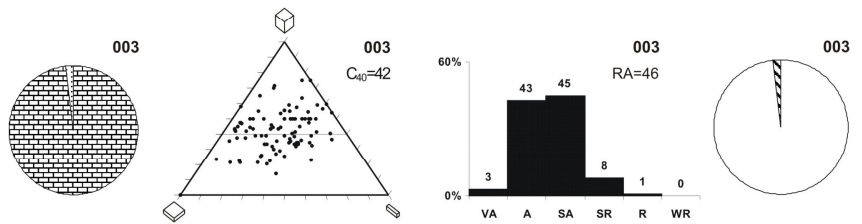

WR - well rounded
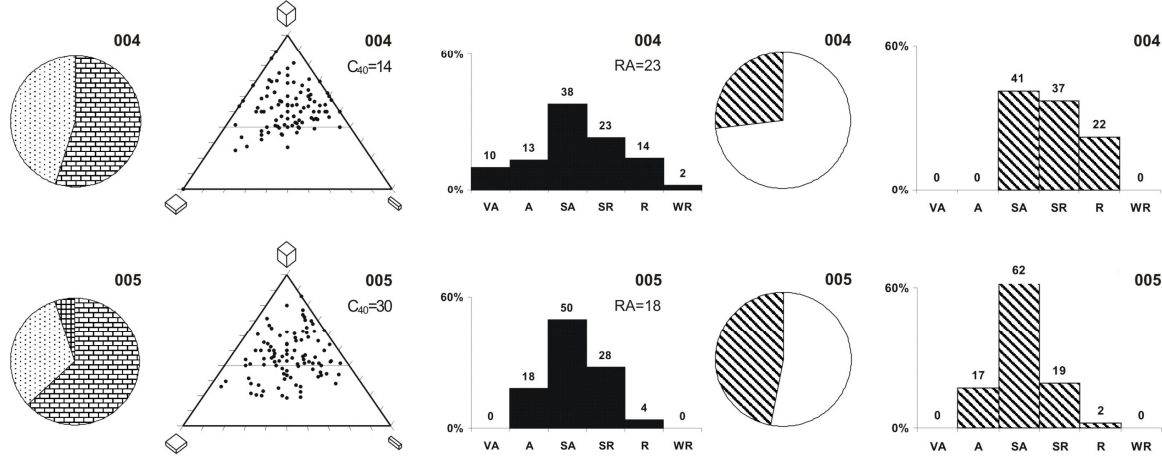

Fig. 9. Petrology, shape, roundness and striation of the clasts in the lateral and frontal moraine. See text for further details.

It originated during largest floods connected with highest periods of glacier ablation. Imbricated clast-supported gravel corresponds to the open framework gravels described by Bridge (2003). It originated by washing out of finer fractions from bar surfaces during culminating flood events or even by wind deflation in dry periods (Gustavson 1974, Boothroyd et Ashley 1975, Bridge 2003). Thin and laterally limited sandy to finegravelly sedimentary mantles were deposited in areas with low energy, such as in small shallow distributing channels on the bar surface or on lee-sides of larger cobbles or boulders (Boothroyd et Ashley 1975, Miall 1977, Bridge 2003). Both facies evolved along the flowline of the main channel within the braidplain. The present bar surface is formed mainly by sorted imbricated gravel facies, where clasts are concentrated in clusters (pebble/cobble cluster sensu Bridge 2003), stone cells textures (Gustavson 1974) are sometimes present as well (see Fig. 7C, F, G). Gravel bar surfaces are sporadically covered by sand to fine-gravel. 

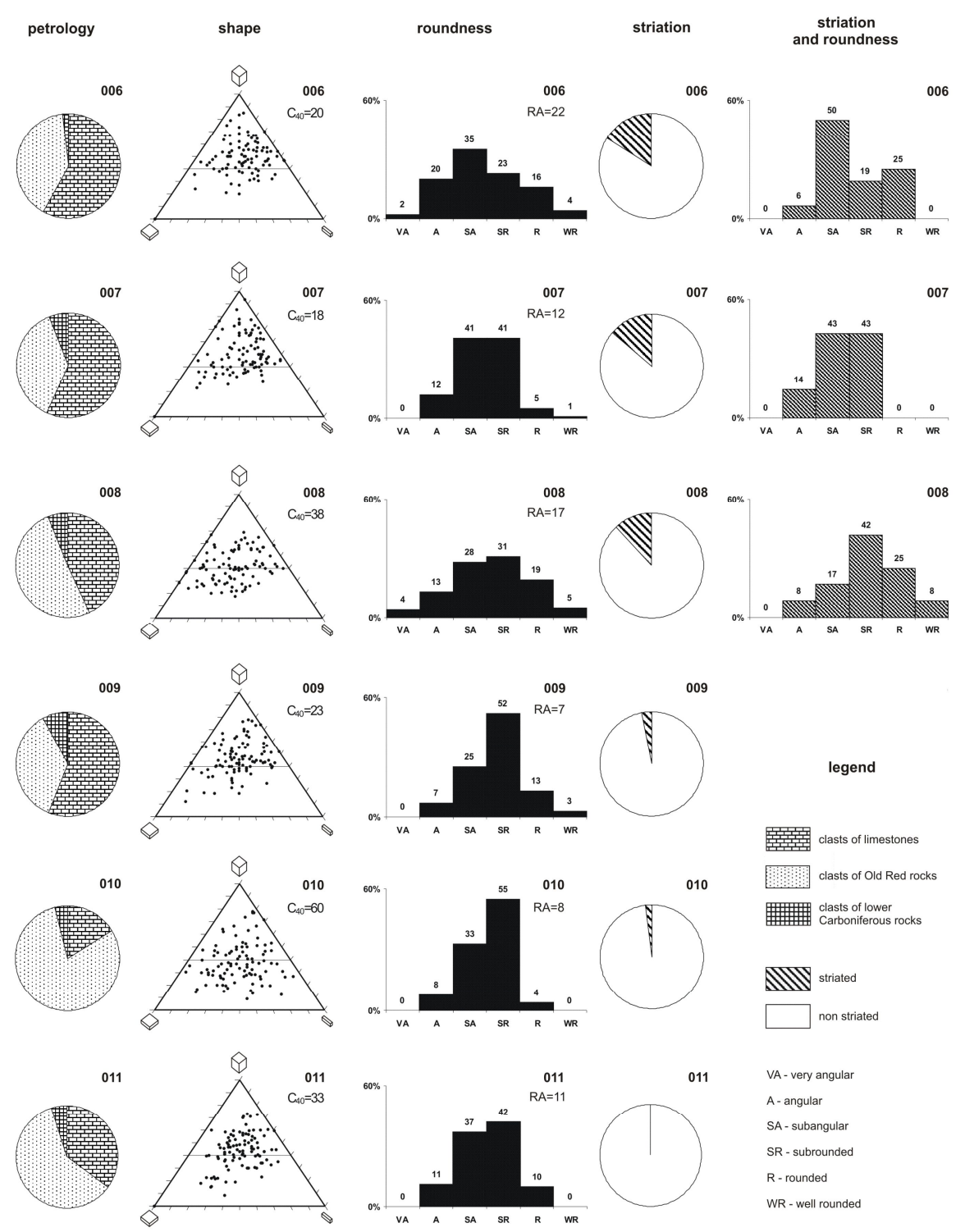

VA - very angular
A - angular
SA - subangular
SR - subrounded
R - rounded
WR - well rounded

Fig. 10. Petrology, shape, roundness and striation of the clasts in the active braidstream and older glaciofluvial terrace. See text for further details.

\section{Proglacial glaciofluvial terrace}

The sedimentary succession records the middle part of a deep channel infill or foresets deposited on the inclined side of a large bar, as it was interpreted by Eynon et Walker (1974). Flat longitudinal bars similar to the active braidplain are cropping out in the upper part of the succession. Thin sandy mantles deposited on bar surface during the declining phase of the flood (c.f. Miall 1977, Benn et Evans 2010). 


\section{Petrology, shape, roundness and clast striation - moraines}

The predominance of very angular and angular clasts is typical for lateral moraines (Benn et Ballantyne 1994, Bennett et al. 1997, 1999, Evans 1999). Very angular to angular clasts represent in lateral moraines scree-originated material, the shape of which has not been modified by subsequent processes (Boulton 1978, Benn et Ballantyne 1994, Hambrey et Ehrmann 2004). In upper parts of lateral moraine are also present subangular and subrounded clasts ( $\sim 35 \%$ for sample 001$)$. These clasts must pass any kind of a preglacial transport or active glacial transport. They could for example have been transported by scree/rock and snow avalanches, for sediments of which higher shares of subangular and subrounded clasts are typical (e.g. Hambrey et Ehrmann 2004). The glacial transport has already been passive. Subrounded and part of subangular clasts might have represent an actively glacially transported material (Benn et Ballantyne 1994, Bennett et al. 1999) or glacially re-deposited older glaciofluvial sediments (Evans 1999). The occurrence of actively transported clasts in lateral moraines of valley glaciers is caused by an oblique movement of glacier tongue in respect to valley sides and thus originally subglacial material might have been transported and deposited at the glacier margin (Benn et Ballantyne 1994, Evans 1999). Scarce clast surface striations suggest a rather low share of the material originating from the glacier base, as clast striation is typical for subglacial transport (Boulton 1978).

The diversity of clast shapes with predominance of intermediate shapes between isometric and platy shapes document different transport history of individual clasts (Fig. 9). Old Red facies clasts are generally more platy and angular than limestone clasts (Fig. 11). The reason for this difference may be the origin of the vast majority of these clasts from unmodified or only minimally modified frost weathered debris above the upper part of right-hand lateral moraine. The more compact limestone clasts may reflect a pre-glacial transport by rock avalanches, where rises compactness of clasts, but does not increase the clast roundness. This is due to clast breakages during the avalanche motion (Evans 1999). Limestone debris had to slide/fall down from higher altitudes, because limestone built the topmost parts of valley sides, while Old Red facies rocks build the valley sides immediately above the lateral moraine. The upper part of the lateral moraine is generally composed of unmodified debris and the material from scree/rock and snow avalanches. The actively glacially transported or reworked older glaciofluvial material is present in a small proportion.

The dominance and well-balanced shares of angular and subangular clasts with abundant very angular clasts in the middle part od lateral moraine illustrate that the material might come from unmodified scree/rock and snow avalanche deposits, as it was shown for lateral moraines by Boulton (1978), Benn et Ballantyne (1994), or Hambrey et Ehrmann (2004). The increase of subangular and subrounded clasts indicates that part of the clasts probably originates from the frontal moraine of a small glacier in a hanging valley. Higher roundness degree is typical for frontal moraines, however it is far from significant for small glaciers (Evans 1999). The proportion of actively glacially transported clasts increase also in each lateral moraine towards the glacier front (Benn et Ballantyne 1994). Therefore it appears that the frontal moraine of the lateral glacier is the main source of the material for the middle part of the lateral moraine of Bertilbreen. 
The influence of bedding and foliations of source rocks on the clast shapes was shown by Bennett at al. (1997). The trend towards platy shapes is reflected also in the $\mathrm{C}_{40}$ index values $\left(\mathrm{C}_{40}=\sim 30-45 \%\right)$, which correspond to the lateral moraines of other valley glaciers (e.g. Benn et Ballantyne 1994, Bennett et al. 1997, Hambrey et Ehrmann 2004). The compactness of a part of the clasts may demonstrate either their subglacial transport in Bertilbreen or the lateral glacier or their transport by rock avalanches (Benn et Ballantyne 1994, Evans 1999).

All studied parameters clearly show that actively transported clasts originating from the subglacial zone predominates in the lower part of the lateral moraine, as could be supported by comparison with numerous similar studies (c.f. Boulton 1978, Benn et Ballantyne 1994, Bennett et al. 1997, 1999, Adam et Knight 2003, Hambrey et Ehrmann 2004). Clast rounding and faceted striated clast surfaces are typical results of traction transport in subglacial zone (Boulton 1978). Clast isometricity increases also with active transport (Boulton 1978), which is reflected in low values of $\mathrm{C}_{40}$ index (Benn et Ballantyne 1994), which for sample 004 has the value of $14 \%$ only. Very angular to angular clasts ( $\mathrm{RA}=\sim 23 \%$ ) in the lower part of the lateral moraine probably originates from unmodified debris; part of the subangular to subrounded clasts can come from scree/rock and snow avalanches (Evans 1999, Hambrey et Ehrmann 2004).

The studied parameters show that subglacially actively transported clasts predominates in the frontal moraine. This interpretation is also supported by findings of subangular to subrounded Lower Carboniferous light sandstone clasts. This sandstone type comes from distant sources (Fig. 4) and had to undergo a relatively long subglacial transport.

The lower part of right-hand lateral moraine and the frontal moraine are very similar from sedimentary petrological point of view. They differ strongly from the middle and upper parts of the lateral moraine by the predominance of actively transported clasts originating from the subglacial zone. The subglacial material was pulled into the marginal parts of the glacier along the thrust planes in the ablation zone of the glacier or by the folding of the material inside the glacier (Boulton 1978, Knight 1994, Bennett et al. 1997, Hambrey et al. 1997, Bennett et Glasser 2010).

\section{Petrology, shape, roundness and clast striation - active braidstream}

The three following factors control clasts' shape and roundness according to our results from Bertilbreen: 1) morphology and composition of surrounding glacial sediments; 2) bedrock lithology; 3) nature of the glaciofluvial stream in individual parts. The influence of these factors is different according to local conditions. Very angular to angular limestone clasts originates from ablationdominant medial moraines, which are formed exclusively by these clasts (Fig. 5C). Very angular to angular clasts of Old
Red facies may come from the valley floor eroded by the glacier directly in the terminoglacial zone. The origin of other clast is rather variable. According to Bennett et al. (1997) clasts of proglacial glaciofluvial sediments originate from reworked subglacial till, as both have similar roundness degree (mostly subangular to subrounded clasts). Glaciofluvial transport should not be too long to modify significantly the original roundness of the clasts. Similar roundness degree is also typical for englacially and supraglacially 
stream-reworked sediments (Hambrey et Ehrmann 2004). Subangular roundness predominates in subglacial glaciofluvial gravel clasts (Bennett et al. 1997). Based on these comparisons and geomorphological and geological situation in the terminoglacial zone of Bertilbreen (ablation moraine elevations, stripes of ablation-dominated medial moraine and relics of older subglacial glaciofluvial sediments in the surroundings of the proglacial stream, see Fig. 5D) the main material sources are ablation moraine, as well as subglacial and englacial glaciofluvial sediments. The ablation moraine is predominantly composed of subglacial material. The subglacial origin of most of the clasts is also supported by abundant striated clast in the sample 006 $(\sim 16 \%)$. The nature of the glaciofluvial sediments in the terminoglacial zone was mainly affected by source rock lithology, rather than by glaciofluvial transport. This illustrates both the roundness variability as well as the stream character in this zone, which is narrow and straight.

The predominance of middle roundness values in the braidplaind just behind the frontal moraine may partly be caused by the change of the source sediments, as the braidplain incised here into subglacial tills. Older glaciofluvial and ablation-dominant medial moraines are not the main source here. Glaciofluvial sediments with the predominance of subangular to subrounded clasts originated according to Bennett et al. (1997) by reworking of subglacial tills. The abundance $(\sim 14 \%)$ of striated clasts, which are largely subangular to subrounded, also points to the origin from subglacial tills. The energy of proglacial glaciofluvial transport is more important here. Longitudinal gravel bars of the proximal braidplain formed during higher floods (Boothroyd et Ashley 1975), when an intensive modification of clasts occurred. The result of the fluvial/glaciofluvial transport is a trend of general rounding of the clasts (Gustavson
1974, Bennett et al. 1999, Hambrey et Ehrmann 2004, Nývlt et Hoare 2011).

Glaciofluvial sediments have two main material sources immediately behind the frontal moraine. The main source is the frontal moraine, which is cut through by the glaciofluvial stream (Fig. 5G). The second important sources are the outcrops of the Old Red sandstone facies, which are eroded by the stream in the forefield of the frontal moraine (Fig. 5G, 7B, 8A). Lessrounded clasts originate from the bedrock outcrops eroded by the stream. The shift towards better rounding, when originally subrounded clasts became rounded, was found for a part of the clasts comparing to the frontal moraine. Limestone clasts originate mainly from the frontal moraine, as they generally round downstream comparing with the sample 005. Limestone in samples 005 and 008 are also very similar in their shapes having platy shapes as the most common ones in both samples.

The influence of the glaciofluvial transport dynamics on the clast rounding dominates in the most distal part of the proglacial glaciofluvial stream, where flat braided outwash fan is formed. The general trend of clast rounding with transport distance in the fluvial braided system is supported by numerous studies (e.g. Gustavson 1974, Bennett et al. 1999, Hambrey et Ehrmann 2004, Nývlt et Hoare 2011). Another factor is the frost shattering, which more easily affects bedded sandstones and siltstones than homogeneous limestones. Old Red facies clasts are less rounded than limestone clasts. They originate partly from outcrops between the frontal moraine and the braided outwash fan. The closest source of limestone clasts is in the frontal moraine, where these clasts have already been partly rounded. Limestone clasts underwent longer glaciofluvial transport and their initial roundness was higher than of sandstones, therefore they are better rounded also in the sample 009. 


\section{Relationships between shapes, roundness and source of the clasts}

Clast shapes in glacial deposits are affected by the presence or absence of foliation in source rocks according to Bennett et al. (1997). Bedding and vertical fissures in the rock outcrops control the general clast shape of Bertilbreen glacial deposits. Sandstone and siltstone of Old Red facies, lower Carboniferous sandstone and siltstone and Carboniferous to Permian limestone have all similar lithological constrains. Significant differentces between limestone and Old Red facies clasts occur in the upper part of the lateral moraine (sample 001), in the frontal moraine (sample 005), in the terminoglacial zone of an active glaciofluvial stream (sample 006), in the braided outwash fan in the most distal part (sample 009), in the older glaciofluvial terrace (sample 010) and in the active glaciofluvial stream down of the canyon (sample 011). The differences are always the same - higher shape variability of the Old Red facies clasts. These clasts are also more angular than limestone clasts in the upper part of the lateral moraine, in the frontal moraine and in the braided outwash fan. These variations lies in a different transport history. In the case of the lateral moraine the clasts originates from unmodified scree material made of Old Red facies. Exhumed outcrops of Old Red facies rocks behind the frontal moraine have been eroded by the glacier and the resulting debris was transported for only a short distance and deposited in the frontal moraine. Part of the Old Red facies clasts in the braided outwash fan originates from the outcrops in the canyon, while limestone clasts may originate closest from the frontal moraine. Old Red facies clasts have been in these two cases transported for a much shorter distance than limestone clasts, therefore their shapes and roundness have not been influenced importantly by glacial and glaciofluvial processes. Increased round- ness with the distance of fluvial and glaciofluvial transport was reported by Gustavson (1974), Bennett et al. (1999), Hambrey et Ehrmann (2004), or Nývlt et Hoare (2011). Roundness of limestone and Old Red facies clasts is similar in the sample 006 from the terminoglacial zone of the active glaciofluvial stream; although the shapes are different. This is caused by a multi-source origin of studied sediment. A part of the Old Red facies clasts probably originates from the bedrock at the valley floor. Very angular to angular limestone clasts were on the other hand carried from the ablation-dominant medial moraines, which are characterized by high angularity. It is evident that the shape variability increases in the smaller fraction (32-64 mm) of samples 010 and 011 .

Fine-grained sandstones are finerbedded than limestones, so they can create smaller and thinner platy shapes, while limestone clasts are more isometric in shapes. An interesting situation is in glaciofluvial sediment (sample 008) in the canyon in front of the frontal moraine, where different clast roundness of Old Red facies and limestone clasts is visible, but the shapes are almost identical for both petrological groups. This example shows, that the shape evaluation alone without the combination with the clast roundness does not provide meaningful interpretations.

Studied sediments cluster into four groups in the covariant diagram of $\mathrm{C}_{40}$ and RA (Fig. 12). The first group with highest values of both studied indices comprises the uppermost sample from the lateral moraine, for which the dominance of passively transported clasts is inferred. Slightly lower values of both indices shows a group of two samples from the middle part of the lateral moraine, which were affected by the material originating from the frontal moraine of a small lateral glacier. The group with lowest values of both indices represents samples from the 
lower part of lateral moraine, frontal moraine and an active braidstream. This group is typical by the dominance of originally subglacially actively transported clasts. The relatively wide dispersion of both indices for samples from an active braidstream is caused by a different nature of the material sources along the stream. The lowest values of both indices shows the material originating from the braided outwash fan. The glaciofluvial transport caused the highest increase in roundness and sphericity of the clasts among all processes in the proglacial zone. The same differences between actively or passively transported glacial sediments were described by Benn et Ballantyne (1994) and Bennett et al. (1997, 1999). The last group consists of the sample from the older glaciofluvial terrace, which differs from other glaciofluvial material by much higher $\mathrm{C}_{40}$ value due to thin platy disintegration of fine-grained sandstone and siltstone Old Red facies.

\section{Relationship of striation with clast petrology and sediment types}

Clasts of all rock types in the terminoglacial and proglacial zone of Bertilbreen are commonly striated. Striae are either subparallel or crossing (Fig. 6). The proportion of striated clasts is large reaching up to $\sim 50 \%$ in the frontal moraine. The frequency of striated clasts is controlled by lithology, as striae are more common on surfaces of sedimentary rock clasts, than crystalline rock clasts. Studies of polar valley glaciers (Bennett et al. 1997) show that striation occurs on surfaces of the half of the studied limestone clasts. Gába (1977) found striation at up to $35 \%$ limestone clasts surfaces at the margin of the Middle Pleistocene ice sheet in Central Europe. Striae are on the other hand not very common on surfaces of crystalline rock clasts (Gába 1977, Bennett et al. 1997).

The distribution of striated clasts in different types of moraines reflects the material origin in the glacier. Striae are formed by the traction transport at the glacier base (Boulton 1978). Their higher shares in frontal moraine and in the lower part of the lateral moraine of Bertilbreen support the hypothesis that the material of these moraines originates from the subglacial zone. Similar results were presented by Bennett et al. (1997). Shares of striated clasts in samples 006-008 from the proglacial glaciofluvial stream in front of Bertilbreen is relatively stable (it's declining slowly from $16 \%$ to $12 \%$ ). A high share of striated clasts demonstrates the key role of the source material on the clast nature in this part of the proglacial stream (ablation moraines, subglacial till, frontal moraine). Our results of striation, together with clast shape analyses confirm for a proximal to medial proglacial glaciofluvial stream conclusions drawn by Bennett et al. (1997), that the glaciofluvial transport is not long enough for a substantial modification of original shapes of clasts. These results correspond also with the conclusions of Hambrey et Ehrmann (2004), according to which the nature of glaciofluvial sediments is affected by the proximity of material source and by the dip of the stream. The share of striated clasts decreases rapidly to $3 \%$ in sample 009 taken from the braided outwash fan. There is a fourfold decrease of the proportion of striated clasts after $\sim 1$ $\mathrm{km}$ of glaciofluvial transport between sample points 008 and 009 . The dominant factor influencing sediments at the braided outwash fan is a high-energetic glaciofluvial transport, because the material sources are distant here. Wiping of striae occurs in the glaciofluvial environment due to clast interactions and they can even disappear from clast surfaces (Hambrey et Ehrmann 2004). 

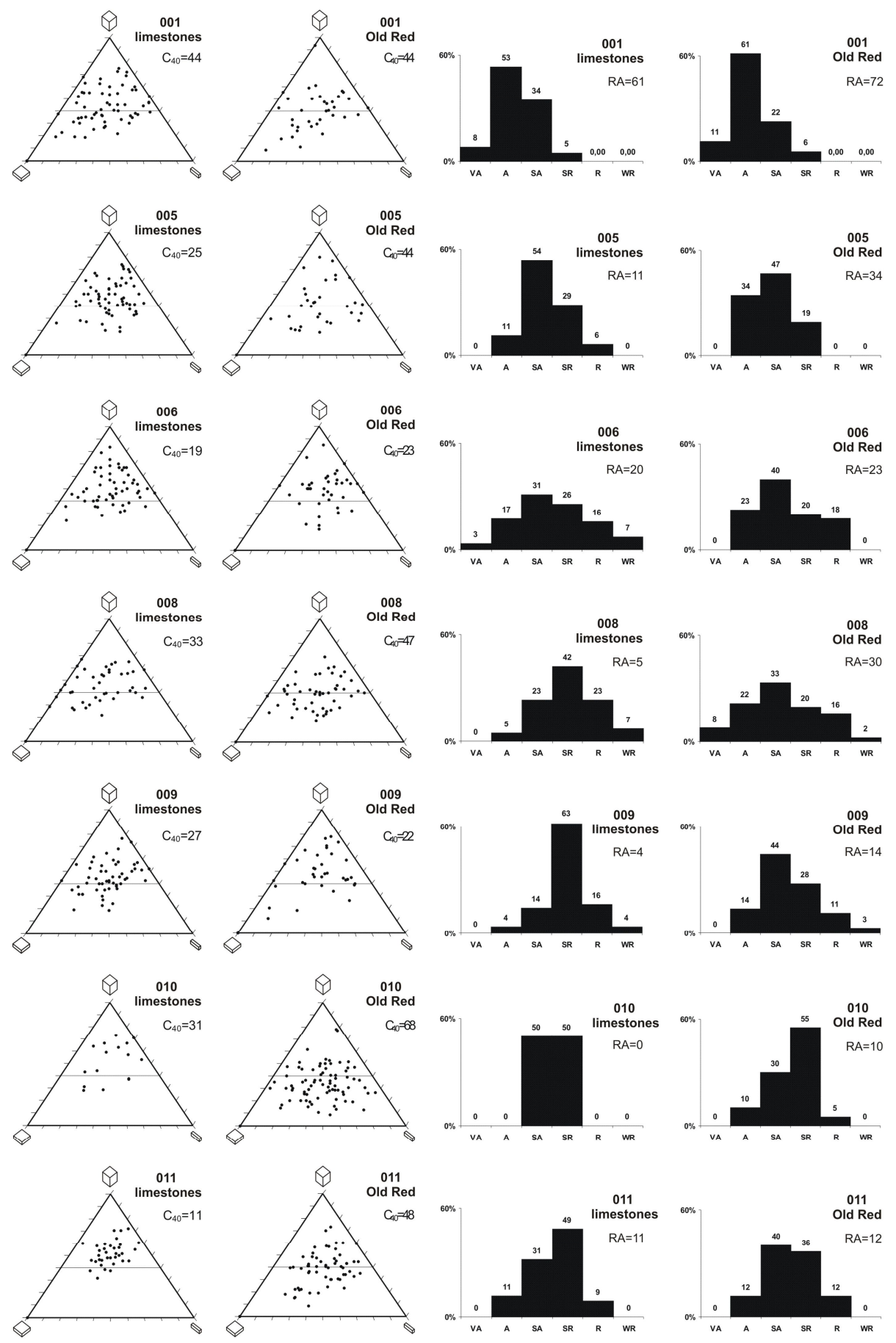

Fig. 11. Shape and roundness differences between limestone and Old Red facies clasts from selected samples. For roundness classes see legend in Figs 9 and 10. 
Sediments of an older glaciofluvial terrace were deposited by a proglacial stream of the advancing Bertilbreen during

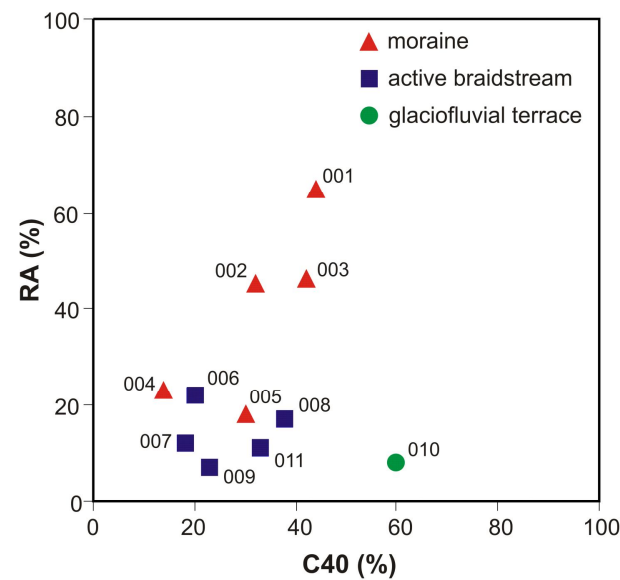

Fig. 12. Covariant plot of $\mathrm{C}_{40}$ versus $\mathrm{RA}$ of all studied samples.

\section{Conclusions}

The surface of the ablation zone of Bertilbreen is covered by stripes of ablation-dominant medial moraine. Ablation moraine elevations are present near the glacier front. Lateral moraines are well preserved on the valley sides of the glacier, merging in the frontal moraine at the glacier terminus. Originally subglacial, englacial and supraglacial sediments lie between the present glacier front and the frontal moraine. The proglacial glaciofluvial stream flowing from the glacier has narrow straight nature at places, however it creates mostly wide braidplain. Flat braided outwash fan is composed at the mouth of the valley. The proglacial stream creates mainly gravely longitudinal bars. A relic of stratigraphically older glaciofluvial sediments is preserved at the southern end of Bertilbreen valley. the LIA according to their morphostratigraphic position and relation to its moraines. In the same time erosion of the valley floor built by Old Red facies rocks begun. Sediments were deposited at the mouth of the Bertilbreen valley into the Mimerdalen valley. During the subsequent warming at the end of the LIA the glaciofluvial stream reached its maximum magnitude and thus the proglacial discharge culminated enabling erosion not only of older glacial deposits, but also excavation of the canyon in the Old Red facies bedrock in front of the frontal moraine. The downcutting of the stream in unconsolidated sediments and bedrock continues till today. This generally reflects the alternations of erosional and aggradational fluvial phases, as described for Quaternary climatic fluctuations by e.g. Starkel (2003).

Three parts may be distinguished in the right-hand lateral moraine. The upper part is predominantly composed of unmodified debris and the material originating from snow and scree/rock avalanches. The actively glacially transported material as well as reworked older glaciofluvial material is present in minor shares. Frontal moraine of a small lateral glacier was the main source of the material for the middle part of the lateral moraine. Actively glacially transported clasts originating from the subglacial zone are on the other hand dominating in the lower part of the lateral and in the frontal moraine. This shows on an important increase of actively transported clasts in moraines towards to glacier front.

Shape, roundness and surface striation of the clasts in active proglacial glaciofluvial stream are controlled mainly by 
adjoining glacial deposits, which are eroded by the stream and represent thus an important material source. Another important material source is the direct erosion of bedrock. The impact of glaciofluvial transport on the clast nature is found to be important not before the braided outwash fan located at the southern mouth of the Bertilbreen valley.

The primary factor controlling the clast shape is bedding and vertical fissures of the source sedimentary rocks. Shape and roundness stage are locally strongly affected by the type and proximity of material sources and also by the rock susceptibility to frost shattering.

Clast surface striation is very common, as the clasts are made of sedimentary rocks, mostly by limestones and sandstones. The presence of striation in morainic sediments is dependent on the clast origin within the glacier system. Very common are striated clasts in the frontal moraine and in adjoining parts of lateral moraines, where most of the clasts originates from the subglacial zone. Striation is on the other hand very rare in parts of lateral moraine, where passive supraglacial transport is predominant. The high-energetic active proglacial stream in the braided outwash fan wipes out clast surface erosional marks, such as striation.

The covariant plot of $\mathrm{C}_{40}$ versus $\mathrm{RA}$ allowed clear discrimination between sediments with predominant passive supraglacial transport and sediments, which were actively subglacially transported. The lowest values of both indices are noted for the material from the braided outwash fan. Thus, the glaciofluvial transport is the most effective process in the proglacial zone leading to an increase in roundness and sphericity of the clasts.

Stratigraphically older glaciofluvial terrace differ from the active proglacial stream by the predominance of Old Red facies clasts and by different lithofacies. This material does not fall in the same range in the covariant $\mathrm{C}_{40} / \mathrm{RA}$ plot as the material from an active glaciofluvial stream due to a specific petrological composition. Sediments of older glaciofluvial terrace have been deposited during the Bertilbreen advance during the LIA. Subsequent warming at the end of the LIA caused the proglacial stream down-cutting creating a canyon in the Old Red facies bedrock. The downcutting of the proglacial stream continues till today.

\section{References}

Adam, W. G., Knight P. G. (2003): Identification of basal layer debris in ice-marginal moraines, Russell Glacier, West Greenland. Quaternary Science Reviews, 22: 1407-1414.

Benn, D. I., Ballantyne, C. K. (1994): Reconstructing the transport history of glacigenic sediments: a new approach based on the co-variance of clast form indices. Sedimentary Geology, 91: 215227.

Benn, D. I., Evans, D. J. A. (2010): Glaciers \& Glaciations. Second Edition. Hodder Education, London, $802 \mathrm{p}$.

Bennett, M. R., Hambrey, M. J. and Huddart, D. (1997): Modification of clast shape in high-arctic glacial environments. Journal of Sedimentary Research, 67: 550-559.

Bennett, M. R., Hambrey, M. J., Huddart, D., Glasser, N. F. and Crawford, K. (1999): The landform and sediment assemblage produced by a tidewater glacier surge in Kongsfjorden, Svalbard. Quaternary Science Reviews, 18: 1213-1246.

Bennett, M. R., Glasser, N. F. (2010): Glacial Geology. Ice Sheets and Landforms. Second Edition. Wiley-Blackwell, Chichester, 385 p. 
Boothroyd, J. C., Ashley, G. M. (1975): Processes, bar morphology, and sedimentary structures on braided outwash fans, northeastern Gulf of Alaska. In: Jopling, A. V., McDonald, B. C. (eds.): Glaciofluvial and Glaciolacustrine Sedimentation. SEPM Special Publication 23: 193-222.

Boulton, G. S. (1978): Boulder shapes and grain-size distributions of debris as indicators of transport paths through a glacier and till genesis. Sedimentology, 25: 773-799.

Bridge, J. S. (2003): Rivers and Floodplains. Form, Processes and Sedimentary Record. Blackwell Publishing, Oxford, $491 \mathrm{p}$.

Dallmann, W. K., Piepjohn, K. and Blomeier, D. (2004): Geological map of Billefjorden, Central Spitsbergen, Svalbard with geological excursion guide. Norsk Polarinstitutt, 2004.

Eynon, G., Walker, R. G. (1974): Facies relationships in Pleistocene outwash gravels, southern Ontario: a model for bar growth in braided rivers. Sedimentology, 21: 43-70.

Evans, D. A. J. (1999): Glacial debris transport and moraine deposition: a case study of the Jardalen cirque complex, Sogn-og-Fjordane, western Norway. Zeitschrift für Geomorphologie, 43: 203-234.

Gába, Z. (1977): Till mit hohem Gehalt der nordischen Kalkgeschiebe von Nová Ves bei Jeseník (Schlesien). Časopis Slezského muzea (A), 26: 185-189 (in Czech, with German summary).

Gustavson, T. C. (1974): Sedimentation on gravel outwash fans, Malaspina Glacier Foreland, Alaska. Journal of Sedimentary Petrology, 44: 374-389.

Hambrey, M. J. (1994): Glacial environments. UCL Press, London, 296 p.

Hambrey, M. J., Ehrmann, W. (2004): Modification of sediment characteristics during glacial transport in high-alpine catchments: Mount Cook area, New Zealand. Boreas, 33: 300-318.

Hambrey, M. J., Huddart, D., Bennett, M. R. and Glasser, N. F. (1997): Genesis of 'hummocky moraines' by thrusting by glacier ice: evidence from Svalbard and Britain. Journal of the Geological Society, London, 154: 623-632.

Knight, P. G. (1994): Two-facies interpretation of the basal layer of the Greenland ice sheet contributes to a unified model of basal ice formation. Geology, 22: 971-974.

Miall, A. D. (1977): A Review of the Braided-River Depositional Environment. Earth-Science Reviews, 13: 1-62.

Miall, A. D. (1985): Architectural-Element Analysis: A New Method of Facies Analysis Applied to Fluvial Deposits. Earth-Science Reviews, 22: 261-308.

Moncrieff, A. C. M. (1989): Classification of poorly-sorted sedimentary rocks. Sedimentary Geology, 65: 191-194.

Nývlt, D., Hoare, P. G. (2011): Petrology, provenance and shape of clasts in the glaciofluvial sediments of the Mníšek member, northern Bohemia, Czechia. Journal of Geological Sciences, Anthropozoic, 27: 5-22.

Powers, M. C. (1953): A new roundness scale for sedimentary particles. Journal of Sedimentary Petrology, 23: 117-119.

Rachlewicz, G., Szczuciński, W. and Ewertowski, M. (2007): Post- „Little Ice Age“ retreat rates of glaciers around Billefjorden in central Spitsbergen, Svalbard. Polish Polar Research, 28: 159186.

Sneed, E. D., Folk, R. L. (1958): Pebbles in the lower Colorado River, Texas, a study in clast morphogenesis. Journal of Geology, 66: 114-150.

Starkel, L. (2003): Climatically controlled terraces in uplifting mountain areas. Quaternary Science Reviews, 22: 2189-2198. 